\title{
Diversity and distribution of sandflies (Diptera: Psychodidae: Phlebotominae) in a military area in the state of Amazonas, Brazil
}

\author{
Luís Henrique Monteiro Gomes $/{ }^{+}$, Maria Ivonei Carvalho Albuquerque, \\ Liliane Coelho da Rocha, Francimeire Gomes Pinheiro, Antonia Maria Ramos Franco
}

Laboratório de Leishmaniose e Doença de Chagas, Coordenação de Pesquisas em Ciências da Saúde, Instituto Nacional de Pesquisas da Amazônia, Manaus, AM, Brasil

This study reports the distribution, ecotopes and fauna diversity of sandflies captured in five training bases on a military reserve in Manaus, state of Amazonas (AM). A total of 10,762 specimens were collected, which were distributed among 58 species, with the highest number recorded at Base Instruction 1 (BII). A higher rate of species richness was found at the Base Instruction Boina Rajada and low levels of diversity associated with a high abundance index with the clear dominance of Lutzomyia umbratilis, Lutzomyia ruii and Lutzomyia anduzei were found at BII. The abundance of Lu. umbratilis raises the possibility of outbreaks of American cutaneous leishmaniasis by the main vector of the disease in $A M$.

Key words: sandflies vectors - military reserve - Manaus

The maintenance of endemic diseases in a given area, particularly those transmitted by vectors such as leishmaniasis, depends on the presence of populations of species involved in the transmission cycle (etiological agents, reservoir hosts and vectors) and environmental conditions that are favourable to their development (Ximenes et al. 2007).

American cutaneous leishmaniasis (ACL) is endemic in Brazil and has three distinctive epidemiological patterns, colonising (i) sylvatic, (ii) occupational/leisure and (iii) rural/periurban areas (MS/SVS 2010). Among the occupational patterns to consider in the epidemiology of ACL is military training (MT) in the jungle, which provides human contact with sandfly vectors of this disease (Paes 1991).

MT in the Amazon jungle occurs throughout the year and cases of ACL have been observed among the soldiers, most likely occurring when they are in the training area, whether while sleeping or during night training, within the Amazon rainforest. In many cases, the diagnosis of human infection is made in other states when these individuals return to their hometowns, which difficult the location of the endemic foci of the disease [Centre for Jungle Warfare Instruction (CIGS), Doctrine and Research Department, unpublished observations].

Outpatient visits conducted by the Institute of Tropical Medicine Manaus, state of Amazonas (AM), Brazil in the period from 1990-2001 recorded 22,066 cases of leishmaniasis in the municipality of Manaus, including 140 cases on military bases from the base instruction (BI) for the CIGS and the 1st Jungle Infantry Battalion (1st BIS), located on AM-010 Road (Manaus-Itacoatiara, AM,

doi: 10.1590/0074-0276108052013018

Financial support: CAPES/RENOR, CNPq/PNOPG, CIGS

+Corresponding author: luis@inpa.gov.br

Received 23 August 2012

Accepted 28 February 2013
Brazil). Due to the occurrence of ACL in military reserve (MR) training in the jungle and the lack of information regarding the presence of vectors in these areas, the present study aimed to identify the diversity of the sandflies and their distribution among five military BIS in Manaus and verify the ecotopes (plateau, hillside and lowland) of the higher occurrence of these insects on this MR.

This study was conducted at the MR located between kilometres 55-70 on the AM-010 highway, which contains approximately 150,000 ha and is $46 \mathrm{~km}$ long. The MR contains five BIS: Boina Rajada (BIBR), Marechal Rondon (BI1), Lobo D'Almada (BI2), Placido de Castro (BI3) and Pedro Teixeira (BI4) (Fig. 1).

The vegetation of the area is primary upland forest with different topographies that can be recognised as plateaus, hillsides and lowlands. BIBR, BI1 and BI2 are located in the jungle plateau, which is characterised by high relief, well-drained clay soil that is nutrient-poor and a canopy of $35-40 \mathrm{~m}$. BI3 is located on the forest hillside, with an area of transition in the lower parts similar to a campinarana, but without the vegetative species that characterise this region and similar to the plateau in the higher parts. The soil has a clayey consistency in the higher parts and a sandyclay consistency in the lower parts. The canopy height is 25-35 m. BI4 is situated in the lowland vegetation, located on the shores of Lake Puraquequara (Manaus), with a forest of campinarana between the lowland areas and hillside. Some areas of BI4 have white sand soil with a large accumulation of leaf litter. Due to the structure of this forest, with dense understory trees and shrubs, greater light penetration is allowed. This area has a canopy height of 15-25 m (Ribeiro et al. 1999).

The capture period was between March 2002-February 2003 for five consecutive days each month and one day on each military base. The specimens were captured and stored using 15 light traps of the "modified" CDC type, with pots attached to the bottom of the trap containing $20 \mathrm{~mL}$ of $70 \%$ alcohol that were installed close to the tree $1 \mathrm{~m}$ from the ground between 05:00 pm-07:00 am. The light traps were arranged in three different di- 
rections, starting at a distance of $100 \mathrm{~m}$ from the military housing (AM) and spaced $50 \mathrm{~m}$ apart.

The sandflies caught were preserved in $70 \%$ alcohol, transported to the laboratory and identified according to the classification of Young and Duncan (1994). The data were analysed according to Roberts and His (1979) with the support of Microsoft Excel 2010, which evaluated the standardised index of species abundance (SISA) with respect to the military bases. Using the software DivEs - Species Diversity version 2.0 (Rodrigues 2007), tests were applied to determine the Shannon-Wiener diversity index (H'), equitability index, Shannon-Wiener index of species richness $(\mathrm{J})$ and first-order jack-knife index of species richness of each area analysed.

A total of 10,762 sandflies (3,759 males and 7,003 females) were identified, distributed among 58 species, with 57 belonging to the genus Lutzomyia and one to Brumptomyia. The species Lutzomyia umbratilis was the most abundant, accounting for 3,529 (32.8\%) samples of the total catch, followed by Lutzomyia ruii $(1,046 / 9.7 \%)$, Lutzomyia anduzei (887/8.2\%), Lutzomyia olmeca nociva (668/6.2\%), Lutzomyia georgii (507/4.7\%), Lutzomyia squamiventris squamiventris (441/4.1\%), Lutzomyia monstruosa (425/3.9\%) and Lutzomyia flaviscutellata (323/3\%) (Table). The greatest number of sandflies were captured in BI1 (4,134/38.4\%), followed by BIBR (3,032/28.2\%), BI2 (2,045/19\%), BI3 (1,049/9.7\%) and BI4 (502/4.7\%).

The species Lu. umbratilis and Lu. ruii were the most abundant in all the areas studied, with SISA $=1.0$. The sandfly $L u$. anduzei obtained a similar rate in BIBR, BI1, $\mathrm{BI} 2$ and $\mathrm{BI} 3$ and 0.9 in BI4. The other species, including $\mathrm{Lu}$. olmeca nociva, Lu. georgii, Lu. squamiventris squamiventris, Lu. monstruosa and Lu. flaviscutellata, exhibited SISA values that ranged from 0.8-0.9 among the military bases.

The sex ratio of the captured species was higher for females at all bases and in all the ecotopes studied. The highest species richness, with an index of $S=50$, occurred in BIBR and BI1. However, the highest diversity index was observed at BI2 $\left(\mathrm{H}^{\prime}=1.239\right)$, followed by BI3

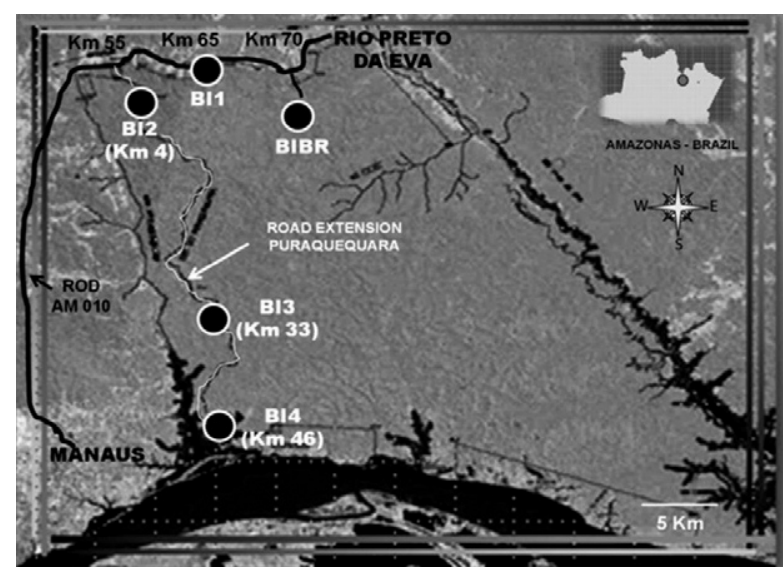

Fig. 1: satellite image of military reserve area in the state of Amazonas, Brazil, showing the distribution of the five bases of instruction (BI) [Marechal Rondon (BI1), Lobo D'Almada (BI2), Placido de Castro (BI3), Pedro Teixeira (BI4) and Boina Rajada (BIBR)]. Source: Instruction Centre Jungle Warfare.
$\left(\mathrm{H}^{\prime}=1.199\right)$. The most significant index of equitability was observed in BI3 $(\mathrm{J}=0.748)$, followed by BI2 $(\mathrm{J}=$ 0.745 ) (Fig. 2). The sandfly distribution among the different ecotopes showed a significant inclination towards the plateau area (9.211/85\%) (Fig. 3) and a high richness index $(S=57)$ for this area. However, the highest diversity index and equitability were recorded for the hillside $\left(\mathrm{H}^{\star}=1.199 ; \mathrm{J}=0.748\right.$, respectively) (Fig. 4).

The most abundant species were $L u$. umbratilis and $L u$. ruii $(\mathrm{SISA}=1.0)$, which were recorded in all three ecotypes, followed by $\mathrm{Lu}$. anduzei (SISA $=1.0 /$ plateau and hillside; 0.9 to lowland), Lu. olmeca nociva and $L u$. georgii (SISA $=0.9$ in all analysed ecotypes), $L u$. squamiventris squamiventris and Lu. monstruosa (SISA $=0.9$ /plateau and hillside; 0.8 to lowland) and Lu. flaviscutellata (SISA $=0.9 /$ plateau and hillside; 0.8 to lowland). In the Brazilian Amazon Region, approximately 200 species of sandflies of the genus Lutzomyia have been recorded (Camargo \& Barcinski 2003), including the main species that transmit leishmaniasis in the region (Young \& Duncan 1994).

A total of 57 species of the genus Lutzomyia were recorded in the present study (Table). Four of these species are incriminated in the Amazon as vectors of ACL, including Lu. umbratilis and Lu. anduzei, which are the main vectors of Leishmania (Viannia) guyanensis and $\mathrm{Lu}$. olmeca nociva and Lu. flaviscutellata, which are involved in the transmission of Leishmania (Leishmania) amazonensis (Arias \& Freitas 1977, 1978, Lainson \& Shaw 1983, Freitas et al. 2002). Similar results with a predominance of $\mathrm{Lu}$. umbratilis in an area of primary forest land using CDC light traps were obtained by Arias and Freitas (1982), Lainson (1983), Dias-Lima et al. (2003), Feitosa and Castellón (2006), Gomes et al. (2009, 2010), Nery et al. (2010) and Soares (2012).

Species such as Lu. squamiventris squamiventris, Lutzomyia davisi, Lutzomyia ayrozai and Lutzomyia paraensis, even though they have a restricted distribution in wild areas and are rarely found in domestic environments (Carvalho et al. 2006), cannot be discarded as potential sources of the emergence of leishmaniasis cases from human contact with these species in the area study, as these species display zoophilic behaviour and bite humans in the forest (Castellón 2009). This possibility may be supported by the recent finding of $L u$. davisi naturally infected with Le. (V.) braziliensis in the Serra dos Carajás (state of Pará), a place where this species may also be involved in the transmission of ACL in the Brazilian Amazon (Souza et al. 2010).

The number of captured specimens varied among the base areas, with a higher incidence of individuals and species richness recorded in BIl and BIBR and the lowest in BI4 (Fig. 2, Table). This distribution can be explained by the geographic location of the study areas (Fig. 1). BIl and BIBR are located near the AM-010 highway (BI1) and are thus closer to residences where waste accumulation caused by local residents was observed, attracting large numbers of synanthropic animals, such as opossums and rodents. These synanthropic animals have great epidemiologic importance because they are reservoirs of Leishmania, with the opossum Didelphis marsupialis regarded as a reservoir for Le. (V.) guya- 


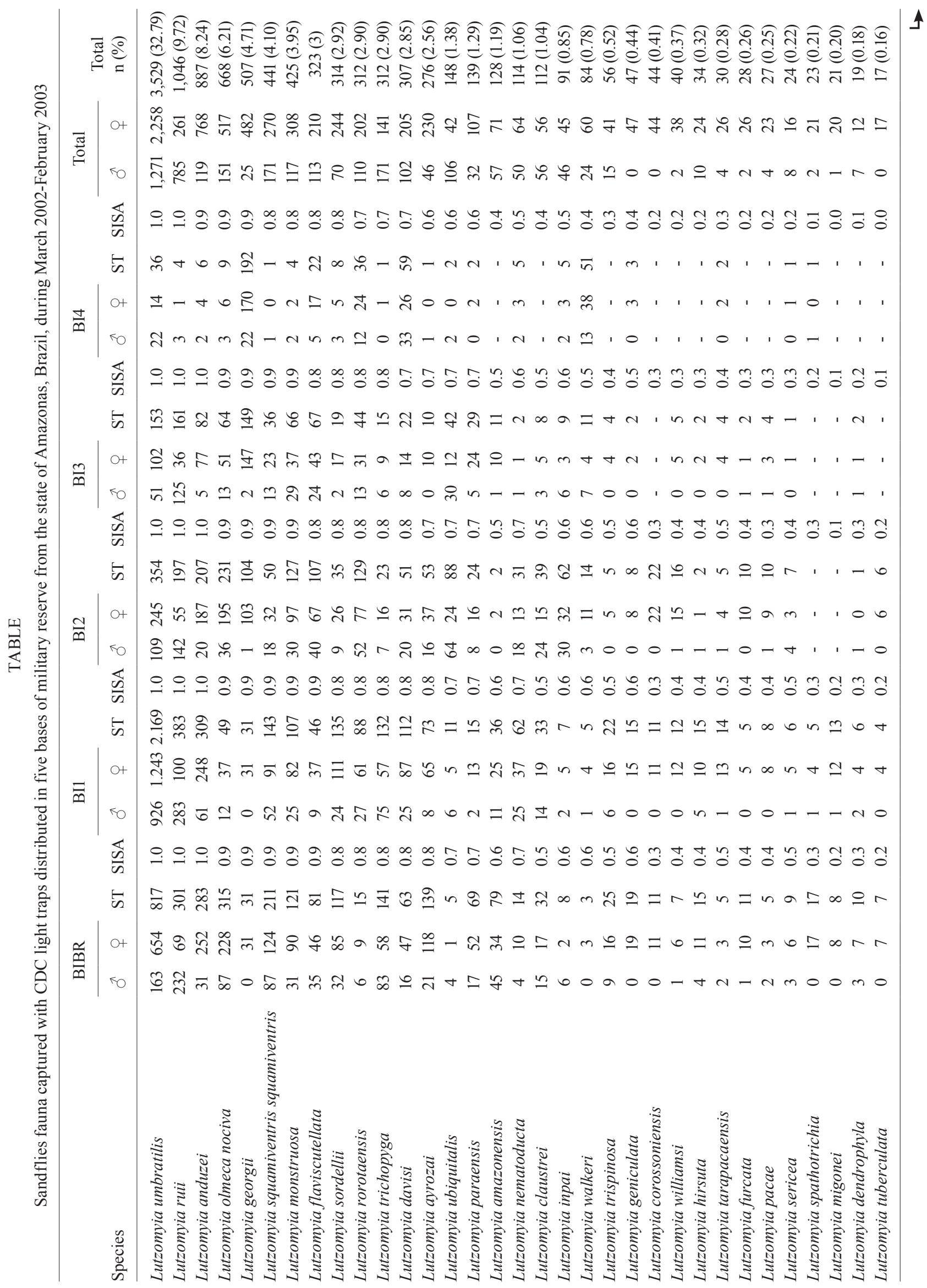




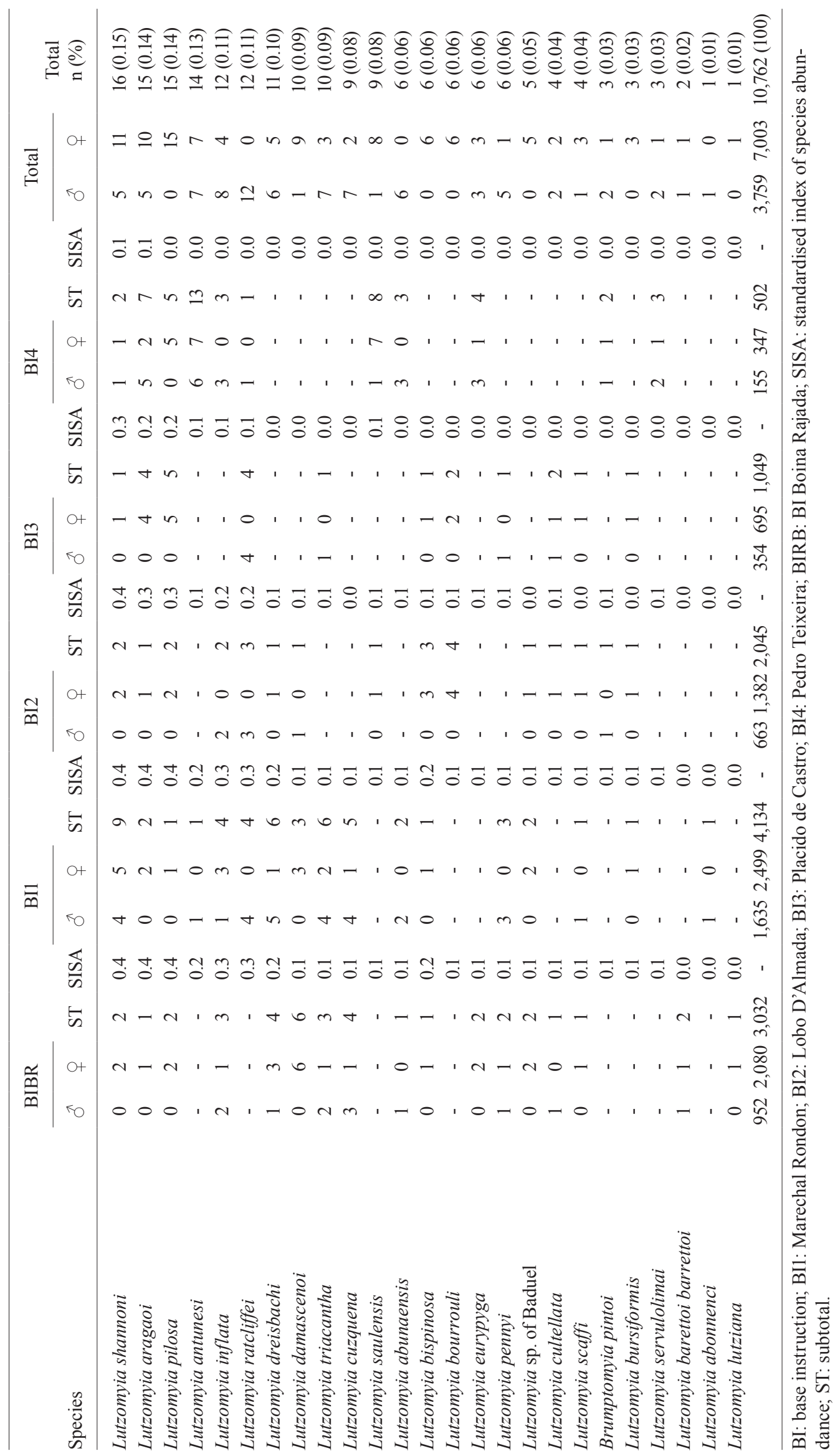


nensis and the rodents Oryzomys sp. and Proechymis sp. as reservoir hosts of Le. (L.) amazonensis (Arias \& Naiff 1981, Lainson \& Shaw 1983).

The highest rates of species diversity were found in $\mathrm{BI} 2$, followed by BI3 and the highest rates of equitability were found for BI3, followed by BI2 (Fig. 2). Despite having a lower richness index than BI1, BI4 revealed higher levels of diversity and equitability. According to Young and Arias (1992), the greatest diversity of species in the genus Lutzomyia is found in the forests in lowlatitude areas of Central America and South America, where 1 ha of forest can contain up to 50 species.

These results can be associated with the topography of the BI4 area, which is located in a lowland area. According to Waite (2000), species richness is simply the number of species that are present. Equitability refers to the relative abundance of each species. In a community with high diversity and equitability, the majority of species that exist have similar levels of abundance and therefore, a clearly dominant species does not occur.

The results presented for BI1, with low diversity and equitability associated with a high abundance index, showed a clear species dominance by $L u$. umbratilis, $L u$. ruii and $L u$. anduzei.

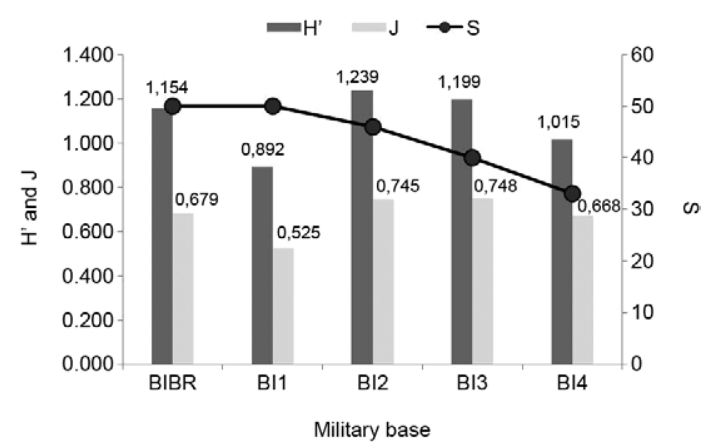

Fig. 2: richness index (S), Shannon-Wiener diversity index (H') and Shannon-Wiener index of species richness (J) of sandfly species captured at five military bases of instruction (BI) [Marechal Rondon (BI1), Lobo D’Almada (BI2), Placido de Castro (BI3), Pedro Teixeira (BI4) and Boina Rajada (BIBR)] in the state of Amazonas, Brazil, during March 2002-February 2003.

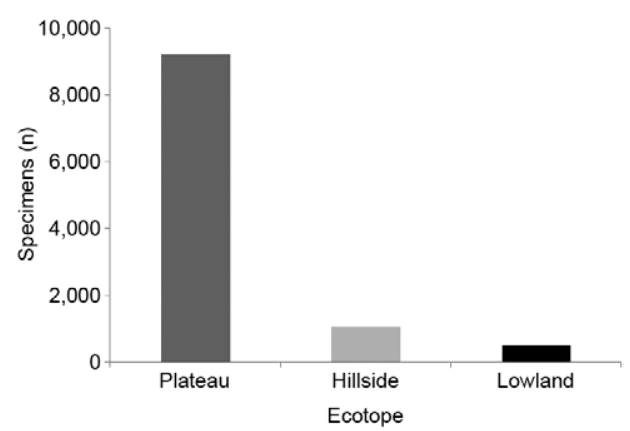

Fig. 3: total number of specimens of sandflies captured in military reserve in the state of Amazonas, Brazil, during March 2002-February 2003.
The distribution of sandfly specimens in different ecotypes showed a higher occurrence in the environment than in the plateau, hillside and lowland for the total prevalence of Lu. umbratilis in the three ecotypes analysed. Ready et al. $(1983,1985)$ and Barrett et al. (1991) showed that populations of Lu. umbratilis are more widely distributed in areas with a high topographic elevation (plateau) that contain large trees with diameters greater than $1 \mathrm{~m}$. Sandflies can be seen resting on the bases of these trees during the day.

In the MR, these characteristics are compatible with the local vegetation of BIBR, BI1 and BI2, which reinforces the suspicion that some outbreaks emerged in BI1 and BIBR in the 1980s, where many trainees become infected with Leishmania (CIGS, Department of Doctrine and Research, unpublished observations).

Chaniotis et al. (1971) observed that in tropical regions, the soil and tree canopy can be viewed as different habitats with different physical and biological components. The canopy is the primary site of flowering and fruiting, which attracts and harbours many vertebrates, such as primates and sloths, which serve as food sources for the sandflies.

The climate in the tree canopy is different from that at the ground level, i.e., there are differences in the microclimate (e.g., temperature, relative humidity, light intensity, air movement and $\mathrm{CO}_{2}$ levels). The lowland ecotope exhibited a lower occurrence of captured individuals. This type of environment is found at BI4, which has cycles of ebb and downstream, flooded areas, forests and understory. This type of environment may not provide the largest gatherings of sandflies as their food sources migrate to other areas during periods of flooding, helping to reduce the population of sandflies.

The constant presence and abundance of $L u$. umbratilis (SISA $=1.0)$ at all BIS is a reason for concern about the possibility of outbreaks of ACL in these military areas, as this species is the main vector of the disease in AM.

The sex ratio was higher for females than males in all areas of the bases for the three ecotopes analysed. This difference is remarkable because the females are the sex that bites, requiring blood to mature their eggs. Consequently, the females are responsible for the transmission of the parasites to humans.

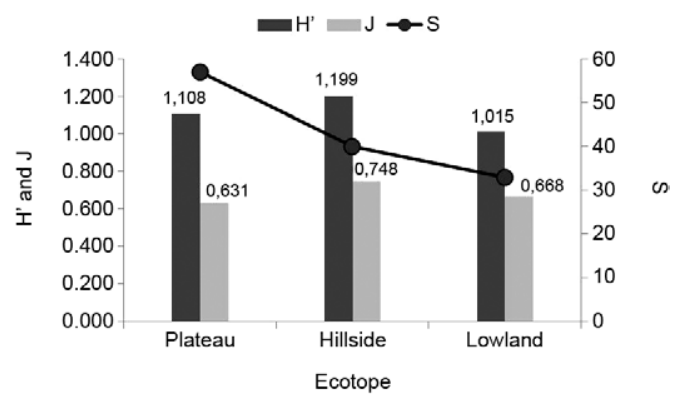

Fig. 4: richness index (S), Shannon-Wiener diversity index (H') and Shannon-Wiener index of species richness (J) of sandfly species captured at five bases of instruction (Marechal Rondon, Lobo D'Almada, Placido de Castro, Pedro Teixeira and Boina Rajada] in the state of Amazonas, Brazil, in different ecotopes, during March 2002-February 2003. 
On-going surveys of the sandfly insect fauna are important to increase our knowledge of the areas where these insects occur, as the comprehension of the population dynamics of this group might be an important factor for the implementation of policies for the epidemiological control of leishmaniasis.

\section{ACKNOWLEDGEMENTS}

To the CIGS, for logistical support, to Maricleide Naiff and Roberto D Naiff, for literature review, and to Plinio Silva, Paulo Albuquerque (in memory), Artemio Silva, Roberto Farias and the technologist Risonilce Fernandes, for technical assistance.

\section{REFERENCES}

Arias JR, Freitas RA 1977. On the vectors of cutaneous leishmaniasis in the Central Amazon of Brazil. Acta Amaz 7: 293-294.

Arias JR, Freitas RA 1978. Sobre os vetores de leishmaniose cutânea na Amazônia Central do Brasil. 2. Incidência de flagelados em flebótomos selváticos. Acta Amaz 8: 387-396.

Arias JR, Freitas RA 1982. On the vectors of cutaneous leishmaniasis in the Central Amazon of Brazil. 3. Phlebotomine sand fly stratification in a terra firme forest. Acta Amaz 12: 599-608.

Arias JR, Naiff RD 1981. The principal reservoir host of cutaneous leishmaniasis in the urban areas of Manaus, Central Amazon of Brazil. Mem Inst Oswaldo Cruz 76: 279-286.

Barrett TV, Freitas RA, Naiff FM, Naiff RD 1991. A leishmaniose e seus transmissores em relação à saúde na Amazônia. In AL Val, R Figliolo, E Feldberg (eds.), Bases cientificas para estratégias de preservação e desenvolvimento da Amazônia: fatos e perspectivas, Secretaria de Ciência e Tecnologia/Instituto Nacional de Pesquisas da Amazônia, Manaus, p. 105-117.

Camargo LMA, Barcinski MA 2003. Leishmanioses, feridas bravas e Kalazar. Cienc Cult 1: 7-34.

Carvalho GML, Falcão AL, Andrade Filho JD 2006. Taxonomic revision of phlebotomine sand fly species in the series davisi and panamensis of the subgenus Psychodopygus Mangabeira, 1941 (Diptera: Psychodidae: Phlebotominae). Mem Inst Oswaldo Cruz 101: 129-136.

Castellón EG 2009. Lutzomyia sand flies in the Brazilian Amazon Basin (Diptera: Psychodidae), INPA, Manaus, 202 pp.

Chaniotis BN, Correa MA, Tesh RB, Johnson KM 1971. Daily e seasonal man-biting activity of Phlebotominae sand flies in Panama. J Med Entomol 8: 415-420.

Dias-Lima AG, Castellón EG, Sherlock I 2003. Flebotomíneos (Diptera: Psychodidae) de uma floresta primária de terra firme da Estação Experimental de Silvicultura Tropical, estado do Amazonas, Brasil. Acta Amaz 33: 303-316.

Feitosa MAC, Castellón EG 2006. Fauna de flebotomíneos (Diptera: Psychodidae) em fragmentos de floresta ao redor de conjuntos habitacionais na cidade de Manaus, Amazonas, Brasil. I. Estratificação Vertical. Acta Amaz 36: 539-548.

Freitas RA, Naiff RD, Barrett TV 2002. Species diversity and flagellate infections in the sand fly fauna near Porto Grande, state of Amapá, Brazil (Diptera: Psychodidae. Kinetoplastida: Trypanosomatidae). Mem Inst Oswaldo Cruz 97: 53-59.

Gomes LHM, Nery LCR, Pinheiro FG, Freitas RA, Franco AMR 2009. Fauna de flebotomíneos (Diptera: Psychodidae: Phlebotominae) em terra firme e planície fluvial na área de influência do gasoduto Coari-Manaus, Amazonas, Brasil. Acta Amaz 39: 233-236.

Gomes LHM, Pinheiro FG, Franco AMR 2010. Infecção e sazonalidade de vetores de leishmaniose em área de treinamento militar no Amazonas. In EGB Castellón, B Ronchi-Teles, R Ale-Rocha (eds.), Entomologia na Amazônia brasileira, Vol. 1, INPA, Manaus, p. 207-219.
Lainson R 1983. The American leishmaniases. Some observations on their ecology and epidemiology. Trans R Soc Trop Med Hyg 77: 569-596.

Lainson R, Shaw JJ 1983. Leishmaniasis in Brazil: 1. Observation on enzootic rodent leishmaniasis - incrimination of Lutzomyia flaviscutellata (Mangabeira) as the vector in the lower Amazonian Basin. Trans R Soc Trop Med Hyg 62: 396-405.

MS/SVS - Ministério da Saúde/Secretaria de Vigilância em Saúde 2010. Manual de vigilancia da leishmaniose tegumentar americana, 2nd. ed., MS/SVS, Brasília, 180 pp.

Nery LCR, Freitas RA, Franco AMR 2010. Fauna de flebotomíneos em fragmento florestal urbano no Amazonas. In EGB Castellón, B Ronchi-Teles, R Ale-Rocha (eds.), Entomologia na Amazônia brasileira, Vol. 1, Instituto Nacional de Pesquisas da Amazônia, p. $247-261$.

Paes MG 1991. Estudo de quatro espécies de Lutzomyia França, 1924 (Diptera, Psychodydae), em área endêmica de leishmaniose tegumentar americana na periferia de Manaus, MsD Thesis, Instituto Nacional de Pesquisas da Amazônia/Fundação Universidade do Amazonas, Manaus, 128 pp.

Ready PD, Arias JR, Freitas RA 1985. A pilot study to control Lutzomyia umbratilis (Diptera: Psychodidae), the major vector of Leishmania braziliensis guyanensis, in a peri-urban rainforest of Manaus, Amazonas state, Brazil. Mem Inst Oswaldo Cruz 80: 27-36.

Ready PD, Lainson R, Shaw JJ 1983. Leishmaniasis in Brazil: XX. Prevalence of "enzootic rodent leishmaniasis" (Leishmania mexicana amazonensis) and apparent absence of "pian bois" (Le. braziliensis guyanensis), in plantations of introduced tree species and in other nom-climax forests in eastern Amazônia. Trans $R$ Soc Trop Med Hyg 77: 775-785.

Ribeiro JEL, Hopkins MJG, Vicentini A, Sothers CA, Costa MAS, de Brito JM, de Souza MAD, Martins LHP, Lohmann LG, Assunção PACL, Pereira EC, da Silva CF, Mesquita MR, Procópio LC 1999. Flora da Reserva Ducke: guia de identificação das plantas vasculares de uma floresta de terra-firme na Amazônia central, Instituto Nacional de Pesquisas da Amazônia, Manaus, 816 pp.

Roberts DR, His BP 1979. An index of species abundance for use with mosquito surveillance data. Environ Entomol 8: 1007-1013.

Rodrigues WC 2007. DivEs - Diversidade de Espécies. Guia do Usuário. Seropédica: Entomologistas do Brasil. Available from: ebras.bio.br/dives/>.

Soares FV 2012. Epidemiologia da leishmaniose tegumentar e a descrição da população flebotomíneos (Diptera: Psychodidae: Phlebotominae) no municipio de Tabatinga, Amazonas, Brasil, MsD Thesis, Instituto Nacional de Pesquisas da Amazônia/Universidade Federal do Amazonas, Manaus, 119 pp.

Souza AAA, Silveira FT, Lainson R, Barata IR, Silva MGS, Lima JAN, Pinheiro MSB, Silva FMM, Vasconcelos LS, Campos MB, Ishikawa EAY 2010. Fauna flebotomínica da Serra dos Carajás, estado do Pará, Brasil, e sua possível implicação na transmissão da leishmaniose tegumentar americana. Rev Pan-Amaz Saude 1: 45-51.

Waite S 2000. Statistical ecology in practice: a guide to analysing evironmental and ecological field data, Prentice Hall, London, $440 \mathrm{pp}$.

Ximenes MAF, Silva VPM, Queiroz PVS, Rego MM, Cortez AM, Batista LMM, Medeiros AS, Jeronimio SMB 2007. Flebotomíneos (Diptera: Psychodidae) e leishmanioses no Rio Grande do Norte, Nordeste do Brasil - Reflexos do ambiente antrópico. Neotrop Entomol 36: 128-137.

Young DG, Arias JR 1992. Flebotomineos vectores de leishmaniasis en las Americas, Organização Pan-Americana da Saúde, Washington, $28 \mathrm{pp}$.

Young DG, Duncan MA 1994. Guide to the identification and geographic distribution of Lutzomyia sand flies in Mexico, the West Indies, Central and South America (Diptera: Psychodidae). Mem Am Entomol Inst 54: 1-881. 